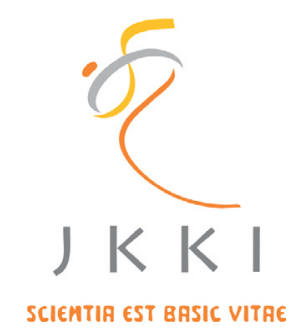

Jurnal Kedokteran dan Kesehatan Indonesia

Indonesian Journal of Medicine and Health

Journal homepage : www.journal.uii.ac.id/index.php/JKKI

\title{
Aedes aegypti vector resistance status on malation and activity of non specific esteration enzymes in Tembalang district, Semarang city
}

Irneta Bela Novita ${ }^{1}$, Martini Martini' ${ }^{2}$, Retno Hestiningsih ${ }^{2}$, Sri Yuliawati², Nissa Kusariana ${ }^{2}$, Mochammad Hadi $^{3}$

${ }^{1}$ Postgraduates Studies Epidemiology, Universitas Diponegoro, Semarang, Indonesia

${ }^{2}$ Faculty of Public Health, Universitas Diponegoro, Semarang, Indonesia

${ }^{3}$ Faculty of Matematics and Science, Diponegoro University, Semarang, Indonesia

Original Article

\begin{tabular}{l}
\hline \\
\hline ARTICLE INFO \\
Keywords: \\
Malathion, \\
Resistance Status, \\
Aedes aegypti, \\
Non-specific esterase enzyme \\
\hline *Corresponding author: \\
belanovita52@gmail.com \\
\hline DOI: 10.20885/JKKI.Vol10.Iss3.art3 \\
\hline History: \\
Received: June 6, 2019 \\
Accepted: October 30, 2019 \\
Online: December 30, 2019 \\
\hline Copyright @2019 Authors. \\
This is an open access article \\
distributed under the terms \\
of the Creative Commons At- \\
tribution-NonCommercial 4.0 \\
International Licence (http:// \\
creativecommons.org/licences/ \\
by-nc/4.0/).
\end{tabular}

\section{ABSTRACT}

Background: Controlling of dengue vectors around dengue haemorrhagic fever cases is often conducted by using insecticides, including a malathion insecticide in the city of Semarang. A research on susceptibility status of Ae. aegypti to insecticides, used for fogging and based on a high number of hemorrhagic fever cases in Tembalang district, Semarang city, needs to be observed.

Objective: This study aimed to determine resistance status of Ae. aegypti mosquitoes based on bioassay and biochemical tests of esterase nonspecific enzyme activity in the Tembalang District.

Methods: This study used a cross sectional design, it was conducted in June-September 2018 in a population of Aedes sp. from Tembalang District, Semarang City. Samples of F2 generations of female Ae. aegypti were obtained by ovitraps in the Tembalang District consisting of 12 urban villages, and their resistance status were tested by impregnated paper bioassay with malathion at a diagnostic dose of $0.8 \%$. Esterase enzyme activity in the Ae. aegypti mosquito body of this population was tested biochemically to prove an increase in a non-specific esterase enzyme on the $\alpha$-naphthyl acetate substrate.

Results: The bioassay results showed that mortality rates of Ae. aegypti at the 12 villages in Tembalang district after 24 hourtest by impregnated paper indicated a range of $0-62 \%$. Mechanism of resistance indicating an increase of non-specific enzyme esterase activity on $\alpha$-naphthyl acetate at Rowosari, Kedungmundu, Sambiroto, and Meteseh could not be seen, It began to be seen in a low percentage (15\%) at Sendang Mulyo, Tandang, Sendangguwo and Bubusan, and in a moderate percentage (45-75\%) in Tembalang, Jangli and Mangunharjo. The mechanism of high esterase enzyme activity could be seen in the Ae. aegypti population at Kramas with $\mathrm{AV} \geq 0,700-0,900$ by a percentage of $20 \%$, and $\mathrm{AV} \geq 0,900$ by a percentage of $80 \%$.

Conclusion: This study provided information about some Ae. aegypti mosquitoes from Tembalang District that showed resistance to the malathion insecticide with an elevation of non-specific esterase enzyme activity on $\alpha$-naphthyl acetate substrate in several villages except Kelurahan Rowosari, Kedungmundu, Sambiroto, and Meteseh. 
Latar Belakang: Pengendalian vektor dengue di sekitar kasus Demam Berdarah Dengue selalu dijalankan dengan menggunakan insektisida malation di kota Semarang. Penelitian status kerentanan Aedes aegypti terhadap insektisida yang digunakan untuk fogging berdasarkan tingginya kasus Demam Berdarah Dengue di kecamatan Tembalang perlu dilakukan.

Tujuan: Penelitian ini bertujuan untuk mengetahui status resistensi nyamuk Aedes aegypti dengan uji bioassay dan biokimiawi enzim esterase nonspesifik di kecamatan Tembalang.

Metode: Penelitian menggunakan desain cross sectional dilakukan pada bulan Juni - September 2018 pada populasi nyamuk Aedes sp dari kecamatan Tembalang kabupaten Semarang. Sampel Ae. aegypti betina generasi F2 hasil penangkapan menggunakan ovitrap di kecamatan Tembalang yang terdiri dari 12 kelurahan telah diuji status resistensinya dengan metode impragnater paper bioassay dengan malation pada dosis diagnostik 0,8\%. Aktivitas enzim esterase pada tubuh nyamuk dari populasi tersebut diuji secara biokimiawi untuk membuktikan adanya peningkatan enzim esterase non-spesifik terhadap substrat $\alpha$-naftil asetat.

Hasil: Hasil bioassay menunjukkan bahwa mortalitas nyamuk Ae. aegypti dari 12 kelurahan di kecamatan Tembalang 24 jam paska pengujian impragnater paper berkisar antara 0-62\%. Mekanisme resistensi yang berupa peningkatan aktivitas enzim esterase non-spesifik terhadap $\alpha$-naftil asetat di kelurahan Rowosari, Kedungmundu, Sambiroto, dan Meteseh belum terlihat, dan mulai terlihat di kelurahan Sendang Mulyo, Tandang, dan Sendangguwo dengan persentase yang rendah (15\%), dan kelurahan Bubusan, Tembalang, Jangli dan Mangunharjo dengan persentase sedang (45-75\%). Mekanisme aktivitas enzim esterase yang tinggi ditunjukkan pada populasi nyamuk Ae. aegypti dari kelurahan Kramas dengan $A V \geq 0,700-0,900$ sebanyak 20\%, dan $A V \geq 0,900$ sebanyak $80 \%$.

Kesimpulan: Penelitian ini memberikan informasi bahwa sebagian nyamuk Ae. aegypti dari kecamatan Tembalang menunjukkan status resisten terhadap insektisida malation dengan mekanisme peningkatan aktivitas enzim esterase non-spesifik terhadap substrat $\alpha$-naftil asetat di beberapa kelurahan kecuali kelurahan Rowosari, Kedungmundu, Sambiroto, dan Meteseh.

\section{INTRODUCTION}

Until now, dengue hemorrhagic fever (DHF) is an inevitable health problem in communities. The DHF is caused by dengue viruses, which transmits through bites of Aedes aegypti mosquitos. ${ }^{1}$ The World Health Organization (WHO) reported that a number of dengue cases each year increased from 0.4 to 1.3 million in 1996-2005, 2.2 million in 2010 and 3.2 million in 2015. ${ }^{2}$

Based on existing reports, the DHF has been endemic in 33 provinces of Indonesia and 436 districts or cities, 605 sub-districts, and 1800 villages or sub-districts. Central Java province is one of the dengue-endemic areas in Indonesia with a number of 14,376 cases, an incidence rate (IR) of 42.26 / 100,000 and a case fatality rate (CFR) of $1.48 \%$ beyond the Indonesian CFR standard of $0.78 \%{ }^{3}$ Semarang is one of dengueendemic cities, especially at Tembalang district which consists of 12 urban villages and has the highest dengue cases. The Tembalang district has 2 primary health cares, namely puskesmas Rowosari and puskesmas Kedungmundu. Incidences of the DHF in Tembalang district in 2016 reached IR of $70.68 / 100,000$ populations and decreased to 36.63 / 100,000 populations in $2017 .^{4}$

A DHF control, namely a controlling vector, is necessary to prevent and stop the dengueendemic transmission. One of the DHF vector eradication programs usually uses insecticides. ${ }^{3}$ Insecticides are the largest group of pesticides used in vector eradication programs for pests and diseases, as well as various types of intruding insects around houses. ${ }^{5}$ Results of interviews with the P2P Department of Health of Semarang City reported that insecticides used for fogging in 2011 were lambda-cyhalothrin; in 20142015 was a malathion insecticide; in 2016 was synthetic pyrethroid (Cynof); and in 2017 until now is d-d trans cyphenothrin $50 \mathrm{~g} / \mathrm{l}$.

Biochemical testing is one of insect susceptibility tests on the insecticides in addition to the WHO standard tests using impregnated paper and molecular tests. This test is to examine 
mosquito resistance on an essential insecticide based on quantification of enzymes responsible for its resistance process. Advantages of the biochemical tests is that the susceptibility status information can be obtained more quickly and can show its resistance mechanism that is measured individually using the esterase enzyme non-specific on $\alpha$-naphthyl acetate. ${ }^{6}$

Based on a previous research on Aedes $s p$ resistance, there was a $77.8 \%$ monooxygenase activity caused by a detoxification enzyme mechanism; therefore, Aedes sp. is a highrisk vector for transmitting dengue viruses in Semarang City. ${ }^{7}$ Another research conducted by Soenjono et al. examining vector Ae. aegypti susceptibility test on malathion in Tomohon City showed that Ae. aegypti was resistant to the malathion insecticide. ${ }^{8}$ It is also similar to Ae. aegypti mosquitos at the Port of Tanjung Emas Semarang which showed resistance to malathion. ${ }^{9}$

In Tembalang district, there is a tendency for resistance on organophosphate insecticides. Ae. aegypti mosquitos as a primary vector need to be examined to determine levels of susceptibility on the insecticides. Based on the discussion above, Purposes of this study is to examine resistance status of Aedes aegypti mosquitoes on malathion and to analyze increases of non-specific esterase enzymes on $\alpha$-naphthyl acetate of Ae. aegypti at each village in the Tembalang district.

\section{METHODS}

This study used analytic observational research and cross-sectional study design. It was conducted on June to November 2018. Its independent variables were exposures of malathion insecticides through impregnated malathion of $0.8 \%$ for 1 hour in Ae. aegypti in the Tembalang district area, while the dependent variables were resistance status of Ae. aegypti and increased activities of the esterase enzyme non-specific on $\alpha$-naphthyl acetate.

\section{Mosquito sample collections}

Aedes agypti mosquitos as research subjects were obtained by ovitraps. Ovitrap installation was used to catch eggs of the Aedes sp. The obtained eggs were bred in the Undip Entomology laboratory and the FK-KMK UGM Parasitology laboratory.

\section{Ae. aegypti larvae survey in residential areas}

An entomological survey in residential areas was conducted at some villages of the Tembalang district, which consisted of 117 urban villages with a total number of 36,371 houses. These study locations were only at 12 villages of the Tembalang district, specifically Tembalang, Bulusan, Kramas, Mangunharjo, Jangli, Tandang, Sambiroto, Meteseh, Kundumundu, Sendangmulyo, Sendangguwo, and Rowosari. Samples of population were larvae Ae. aegypti from water reservoirs at residents' homes at the 12 villages, Tembalang district, Semarang city.

Referring to a calculation of a Lemeshow cross-sectional formula, this study had 40 samples in each 12 villages, so that the total samples in this study were 480 houses.

\section{Bioassay}

Standard kits for vulnerability testing consisted of 4 test tubes and a pair of control tubes. Each tube was filled with 25 healthy female mosquitoes with a total number of 125 mosquitoes. The tests were conducted at the 12 villages in which each village had 125 mosquitoes; therefore, 12 villages consisted of 1,500 mosquitoes. The tests used impregnated paper containing $0.8 \%$ malathion insecticides, while in control groups the tests used mineral oil of impregnated paper which did not contain insecticides. The mosquitoes were contacted for 60 minutes in a contact tube, and the numbers of dead mosquitos were recorded. Then the dead mosquitos were transferred in to a collector tube and were placed in fresh air for 24 hours (holding) by giving sugar water. The number of the dead mosquitoes after 24 hours in a recovery tube was calculated.

Criteria to determine resistance status were established according to WHO standards in 2016: percentage of deaths $\geq 98 \%$ = susceptible 
(SS), $90-97 \%=$ tolerant (RS) and needs to be confirmed molecular resistance mechanism, $<90 \%=$ resistant (RR) and does not need to be confirmed with other bioassay methods if a minimum number of 100 mosquitoes test. ${ }^{9}$

\section{Biochemical Test}

Early third instar larvae of the F2 generation crushed individually to be made homogenate and dissolved with $0.5 \mathrm{ml}$ of phosphate buffer saline (PBS) solution. $0.02 \mathrm{M}$ homogenate, 50 $\mu \mathrm{l}$ by micropipette and put into the microplate wells. For each well, then $50 \mu \mathrm{l}$ of prepared substrate materials was added, specifically: $3 \mathrm{mg}$ of $\alpha$-naphthyl acetate was dissolved into $0.5 \mathrm{ml}$ acetone, and then $100 \mu$ l was taken to be added to BPS until a volume of a substrate solution became $10 \mathrm{ml}$. The solution inside a microplate well was left for 60 seconds.

Each microplate well containing $50 \mu \mathrm{l}$ homogenate and $50 \mu \mathrm{l}$ substrate was added by $50 \mu$ coupling reagent (coupling reagent $=30 \mathrm{mg}$ fast blue and $7 \mathrm{ml}$ SDS $5 \%+3 \mathrm{ml}$ aquadest). Then it was allowed to stand for 10 minutes while observing color changes arising from red color to be blue gradually. This reaction was stopped by adding $50 \mu \mathrm{l}$ of $10 \%$ acetic acid solution. The non- specific enzyme activity (absorbence value) was then read with an ELISA reader at a wavelength $(\lambda)$ of $450 \mathrm{~nm}$. Relationships of resistance status and resistance mechanism based on an increase in the activity of the esterase enzyme non-specific on $\alpha$-naphthyl acetate were grouped as the following: absorbance value (AV) $<0,700$ (very susceptible/ SR); AV $\geq 0,700-0,900$ (medium resistance/ $\mathrm{RS}$ ); $\mathrm{AV}>0,900$ (high resistance).

\section{Ethical Clearance}

No. 131/ EC/ H/ FK-UNDIP/ XII/ 2018, Ethics Committee of Faculty of Medicine, Universitas Diponegoro, Semarang

\section{RESULTS \\ Bioassay results}

Test results of Ae. aegypti mosquito susceptibility based on the impregnated paper method containing $0.8 \%$ malathion active ingredients were presented in Table 1 . Table 1 demonstrated that the highest percentage of dead mosquitos observed for 24 hours after treatment was at Sendangmulyo (49\%), while the lowest was at Sambiroto (0\%). Ae.aegypti from all 12 villages were resistant to the malathion insecticides.

Table. 1. Resistance status of Aedes aegypti mosquitoes at 12 villages in Tembalang district on malathion based on an impregnated paper test with a diagnostic dose of malathion $(0.8 \%)$

\begin{tabular}{lcccc}
\hline \multirow{2}{*}{ Villages } & $\begin{array}{c}\text { Numbers of tested } \\
\text { mosquitos * }\end{array}$ & \multicolumn{2}{c}{ Mosquito mortality 24 hours after treatment } & Resistance \\
\cline { 3 - 4 } & 100 & Numbers of death & Percentages (\%) & Status \\
\hline Sendangmulyo & 100 & 49 & Resistant \\
Bulusan & 100 & 41 & 41 & Resistant \\
Tembalang & 100 & 39 & 39 & Resistant \\
Keramas & 100 & 33 & 33 & Resistant \\
Tandang & 100 & 16 & 16 & Resistant \\
Sendangguwo & 100 & 61 & 61 & Resistant \\
Rowosari & 100 & 2 & 2 & Resistant \\
Jangli & 100 & 13 & 13 & Resistant \\
Mangunharjo & 100 & 32 & 32 & Resistant \\
Kedungmundu & 100 & 19 & 19 & Resistant \\
Sambiroto & 100 & 0 & 0 & Resistant \\
Meteseh & 100 & 8 & 8 & Resistant \\
\hline * Four replications
\end{tabular}

* Four replications, 25 mosquitoes for each sample in each district 


\section{Biochemical Test Results}

Results of biochemical test of the non-specific esterase enzyme activity on $\alpha$-naphthyl acetate substrate in the Ae. aegypti larvae population in 12 villages in the Tembalang district were presented in Table 2 below.

Table. 2. Non-Specific Esterase Enzyme Activity On A-Naphthyl Acetate Substrate In Aedes aegypti mosquito population in Tembalang district based on a biochemical test by reading Elisa Reader $=\lambda 450 \mathrm{~nm}$

\begin{tabular}{|c|c|c|c|c|c|c|}
\hline \multirow{3}{*}{ Villages } & \multicolumn{6}{|c|}{ Absorbance Levels } \\
\hline & \multicolumn{2}{|c|}{$\begin{array}{c}(A V<0,700) \\
\text { Low }\end{array}$} & \multicolumn{2}{|c|}{$\begin{array}{c}(A V \geq 0,700-0,900) \\
\text { Middle }\end{array}$} & \multicolumn{2}{|c|}{$\begin{array}{c}(A V \geq 0,900) \\
\text { High }\end{array}$} \\
\hline & Numbers & $\%$ & Numbers & $\%$ & Numbers & $\%$ \\
\hline Sendangmulyo & 17 & 85 & 1 & 5 & 2 & 10 \\
\hline Bulusan & 11 & 55 & 6 & 30 & 3 & 15 \\
\hline Tembalang & 10 & 50 & 5 & 25 & 5 & 25 \\
\hline Kramas & 0 & 0 & 4 & 20 & 16 & 80 \\
\hline Tandang & 17 & 85 & 2 & 10 & 1 & 5 \\
\hline Sendangguwo & 17 & 85 & 1 & 5 & 2 & 10 \\
\hline Rowosari & 20 & 100 & 0 & 0 & 0 & 0 \\
\hline Jangli & 7 & 35 & 9 & 45 & 4 & 20 \\
\hline Mangunharjo & 5 & 25 & 10 & 50 & 5 & 25 \\
\hline Kedungmundu & 20 & 100 & 0 & 0 & 0 & 0 \\
\hline Sambiroto & 20 & 100 & 0 & 0 & 0 & 0 \\
\hline Meteseh & 20 & 100 & 0 & 0 & 0 & 0 \\
\hline
\end{tabular}

Table 2 indicated that an increase in the activity of the non-specific esterase enzyme on $\alpha$-naphthyl acetate is not a resistant mechanism of the Ae. aegypti. Those were resistant to the malathion insecticides were at Rowosari, Kedungmundu, Sambiroto, and Meteseh due to their low percentage (100\%). The mechanism of increasing esterase enzyme activity was seen in Sendang Mulyo, Tandang and Sendangguwo with a low percentage (15\%), and Bubusan, Tembalang, Jangli and Mangunharjo with average percentages (45-75\%). The mechanism of high esterase enzyme activity was shown in the Aedes mosquito population in Kramas with $\mathrm{AV} \geq 0,700$ 0,900 by a percentage of $20 \%$, and $A V>0,900$ by a percentage of $80 \%$.

\section{DISCUSSION}

The results of the resistance test on the malathion insecticides indicated that Ae aegypti at the 12 villages in Tembalang district were resistant to insecticides. These results were in line with the Ae. aegypti at Rukukan, Tomohon city which were resistant to the malathion insecticides.

The observation results of esterase enzyme activity of mosquito populations at the 12 villages showed that the most significant percentage of the mosquitos increasing in the enzyme esterase activity was in Kramas, with moderate $(20 \%)$ and high (80\%) level of the activity.

This result was in line with the percentage of the dead mosquitos in the bioassay results. The resistance status meant that the resistance status of Ae. aegypti on the malathion insecticides in Kramas could be associated with an increase in the esterase enzyme activity. The increase of the activity indicated a metabolic detoxification mechanism in the insect's body. Esterase is one of the detoxification enzymes known to play 
roles in the mechanism of insect resistance to insecticides from organophosphate groups. The esterase is one of the hydrolase enzyme groups, a large group of enzymes that catalyzes hydrolysis reactions of aliphatic compounds, aromatic esters, choline esters andorganophoshorus. ${ }^{10}$

This information is essential to be used as a basis to select replacement insecticides when rotating the insecticide replacement. Moderatehigh esterase enzyme activity in the Ae. aegypti population at some villages in Tembalang district can allow resistance to insecticide compounds beside the malathion, which also has an ester group. Organophosphates are esters of phosphoric acid or thiophosphoric acid so that all insecticides from the organophosphate group have esters. In addition to organophosphates, insecticides from the carbamate group also contain an ester group because carbamate insecticides are esters of $\mathrm{N}$-methyl carbamic acid. $^{11}$

At four other villages (Rowosari, Kedungmundu, Sambiroto, Meteseh), each of the four village had a low level of esterase activity, so it was not in line with the percentage of the number of the dead mosquitos in bioassay results indicating resistance status. This condition indicated that the resistance status of Ae. aegypti of malathion insecticides at the four villages was not related to an increase in the activity of the enzyme esterase, meaning there was no resistance to the malathion.

In the villages that did not show presence of esterase enzyme activity, there might have changes in its carboxylesterase enzyme. However, this study did not assess whether there was specific a mechanism. The carboxylesterase enzyme could hydrolyze one or both carboxylate groups making up the malathion compounds. If the carboxylic group making up the malathion compounds changed, this insecticide compounds would lose their functions. Resistance caused by enzyme activity usually occurs when the enzyme blocks the insecticide compounds from reaching their targets. ${ }^{12}$
Tackling problems of the resistance in addition to controlling uses of the insecticides in a controlled and directed manner is also necessary to replace uses of chemical insecticides such as organophosphate with bioinsecticides and mosquito breeding programs (PSN) that are encouraged by the Indonesian government (drain, cover, bury) and are supported by public awareness to maintain hygiene and health. ${ }^{3}$

\section{CONCLUSION}

This research provides information of $A e$. Aegypti at 12 villages in Tembalang district that showed resistance status to malathion insecticides with a mechanism of increasing nonspecific esterase enzyme activity on $\alpha$-naphthyl acetate substrate in the villages except Rowosari, Kedungmundu, Sambiroto, and Meteseh.

\section{CONFLICT OF INTEREST}

None declare.

\section{ACKNOWLEDGEMENT}

The author thanks the Head of Semarang City Office and staff of puskesmas Kundumundu, and puskesmas Rowosari for supporting this study. In addition, the author thanks to technical colleagues in the Undip Entomology laboratory Installation and the FK-KMK UGM Parasitology laboratory that assisted for implementation of bioassay and biochemical tests.

\section{REFERENCES}

1. WHO. Demam berdarah dengue: diagnosis, pengobatan, pencegahan \& pengendalian (Edisi 2)EGC Jakarta.; 2016.

2. WHO. Media center dengue and dengue haemorrhagic fever. Jakarta: WHO; 2016.

3. Kementerian Kesehatan RI. Pedoman pengendalian demam berdarah dengue di Indonesia. Dirjen P2P\&PL. Jakarta; 2016.

4. Dinas Kesehatan Kota Semarang. Profil kesehatan kota Semarang 2016. Dinas Kesehat Kota Semarang. 2017:1-102.

5. Kementerian Kesehatan RI. Pedoman penggunaan insektisida (pestisida) dalam 
pengendalian vektor.Jakarta; 2012.

6. WHO. Monitoring and managing insecticide resistance in Aedes mosquito populations Interim guidance for entomologists. Geneva: WHO. 2016

7. Martini HR, Widjanarko B, Purwantisari S. Resistance of Aedes as a vectors potential for dengue hemorrhagic fever ( DHF) in Semarang city, Indonesia. Journal Of Tropical Life Science. 2019;9(1):89-94.

8. Soenjono SJ, Pandean M. Status resistensi vektor demam berdarah dengue Aedes aegypti terhadap malathion di kota Tomohon resistance status of Aedes aegypti against malathion, in Tomohon city. 2017; $11(2): 43-8$.

9. Iswidaty, T., Martini. WD. Status resistensi nyamuk Aedes Aegypti terhadap malathion $0,8 \%$ di area perimeter dan buffer pelabuhan Tanjung Emas Semarang (pengujian berdasarkan teknik bioassay dan biokimia). Jurnal Kesehatan Masyarakat Universitas Diponegoro. 2016;4(1):211-7.

10. Jackson CJ, Liu J, Carr PD, et al. Structure and function of an insect $\alpha$-carboxylesterase ( $\alpha$ Esterase 7 ) associated with insecticide resistance. 2013;110(25):10177-82.

11. Raini M. Toksikologi pestisida dan penanganan akibat keracunan pestisida. Media Penelitian dan Pengembangan Kesehatan. 2007.17 (3):10-8

12. Widiastuti D, Ikawati B. Resistensi malathion dan aktivitas enzim esterase pada populasi nyamuk Aedes aegypti di kabupaten Pekalongan Malathion Resistance And Esterase Enzyme Activity Of Aedes aegypti Population In Pekalongan. BALABA. 2016.12 (2):61-70. 